\section{Original Research}

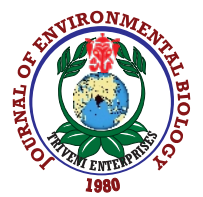

DOI : http://doi.org/10.22438/jeb/41/2(SI)/JEB-11

\title{
Simultaneous removal of nitrate and pesticide endo- sulfan in groundwater using membrane biofilm reactor
}

\author{
Y. Cuci* and E.G. Taşkın \\ Department of Environmental Engineering, Kahramanmaraş Sütçülmam University, Kahramanmaraş - 46050, Turkey \\ *Corresponding Author Email : cuci@ksu.edu.tr
}

\section{Abstract}

Aim: In this study, a hydrogen-based membrane biofilm reactor $\left(\mathrm{H}_{2}-\mathrm{MBfR}\right)$ was operated to investigate the simultaneous removal of endosulfan and nitrate.

Methodology: The MBfR was fed with synthetic groundwater prepared and operated at constant $\mathrm{pH}(7.2)$ and temperature $\left(30^{\circ} \mathrm{C}\right)$. The membrane bundle consisted of 40 hollow fiber membranes with an active length of $10 \mathrm{~cm}$ and surface area of $0.0078 \mathrm{~m}^{2}$. The $\mathrm{H}_{2}-\mathrm{MBfR}$ was operated for 237 days with varying influent nitrate concentrations (2.25-10 $\left.\mathrm{mg} \mathrm{N} \mathrm{I}^{-1}\right)$, hydraulic retention times (HRT, $0.5-12 \mathrm{hr})$, hydrogen pressures (2-6psi), and endosulfan concentrations (0.1-10 $\left.\mu \mathrm{gl}^{-1}\right)$.

Results: The study results showed that complete denitrification and endosulfan removal above $99 \%$ could be achieved when influent endosulfan concentration was $1 \mu \mathrm{g} \mathrm{I}^{-1}$ with an HRT of $1 \mathrm{hr}$, nitrate concentration of $10 \mathrm{mg} \mathrm{N} \mathrm{I}^{-1}$, and $\mathrm{H}_{2}$ pressure of $6 \mathrm{psi}$. Increasing endosulfan concentration to $10 \mu \mathrm{g} \mathrm{I}^{-1}$ decreased denitrification rate from 99 to $93 \%$.

Interpretation: The $\mathrm{H}_{2}-\mathrm{MBfR}$ presented here has proved to be efficient for depuration of water contaminated with nitrate and pesticide endosulfan.

Key words: Drinking water, Endosulfan, $\mathrm{H}_{2}-\mathrm{MBfR}$, Nitrate

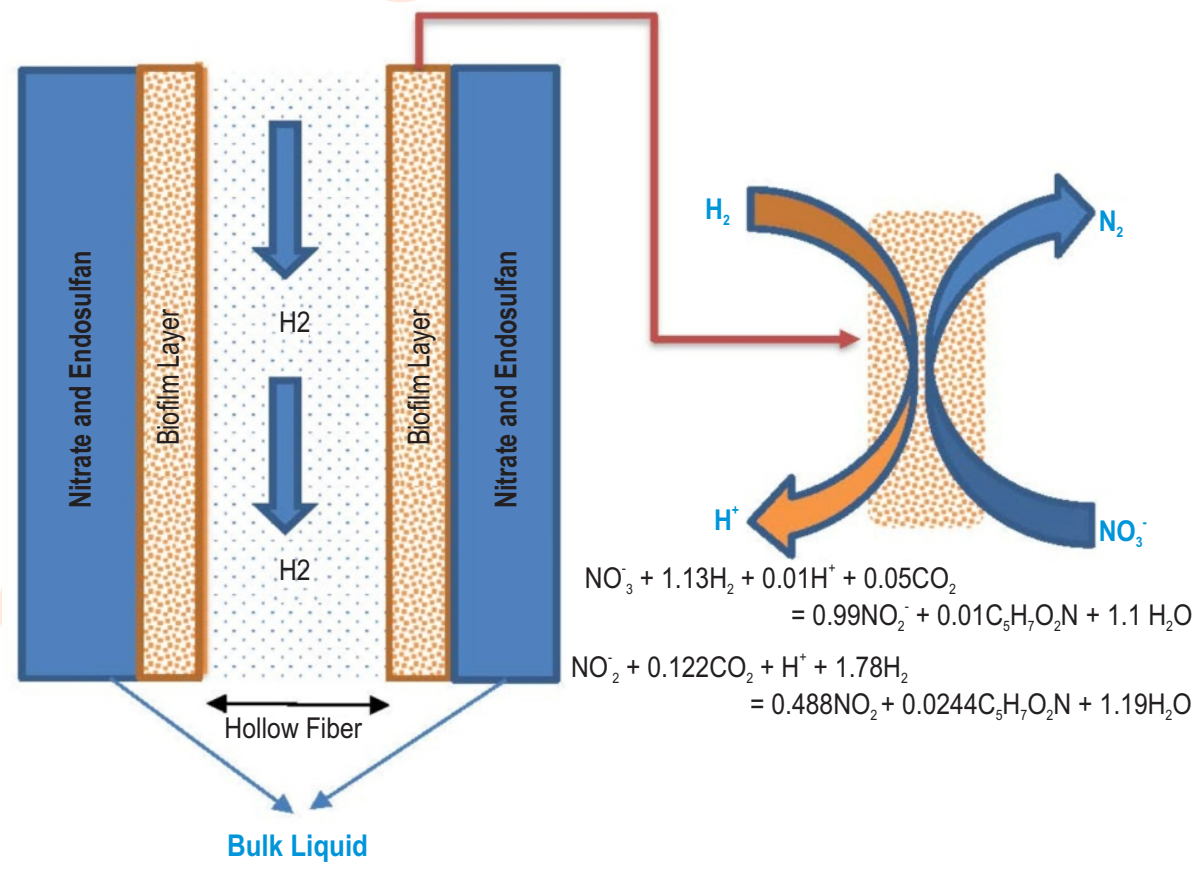

How to cite : Cuci, Y. and E.G. Taşkın: Simultaneous removal of nitrate and pesticide endosulfan in groundwater using membrane biofilm reactor. J. Environ. Biol., 41, 351-357 (2020). 


\section{Introduction}

Contamination of groundwaters; which are the major source of drinking water; is mainly contaminaed with nitrogen and pesticide originating from the use of chemical fertilizers is a matter of concern. Nitrogen is mainly found in groundwaters in the form of nitrate and nitrite nitrogen. High nitrate level in water can cause methemologlobinemia or blue baby disease in humans, especially in infants under six months (Wester man and Bicudo, 2005; Mirvish, 2013; Ozturk et al., 2013, Hakeem et al., 2011, 2017). EPA's maximum contaminant level for nitrate set to 10 $\mathrm{mg} / \mathrm{L}$, whereas the drinking water Directive $(98 / 83 / \mathrm{EC})$ sets a maximum allowable concentration for nitrate of $50 \mathrm{mg} \mathrm{l}^{-1}$. Besides, pesticides such as endosulfan are highly toxic chlorinated organic compounds even if in micro levels, and due to long half-lives, they are highly persistent in the environment (Nerenberg and Rittmann, 2004). Endosulfan concentration is often low compared to surface waters which ranges between $(0.21-54$ ng I') (ATSDR, 2015). These contaminants adversely affect ecological system and threat human health through drinking water (Ozturk et al., 2012; Feng et al., 2015), therefore, increasing chemical pressure in drinking water supplies. Therefore, there is need to take these into account.

Removal of nitrogen has become one of the most important concerns in water pollution control (Rittmann and Asce, 2009). Biological nitrogen $(\mathrm{N})$ removal is widely performed by autotrophic nitrification coupled to heterotrophic denitrification. In general, nitrification requires anaerobic environment for oxidation of ammonium to nitrite (phase I) and then to nitrate (phase II) whereas heterotrophic denitrification occurs by utilizing organic electron donors under anoxic condition. However, groundwaters contaminated with nitrate have almost no organic carbon, the hetetrophic denitrification process remains inoperative. The autotrophic denitrification which uses inorganic electron source makes it a sustainable solution (Shin et al., 2015; Ergas and Reuss, 2001; Lee and Rittmann, 2002).

Autotrophic denitrification can be achieved by so many inorganic electron donors such as hydrogen (Puig et al., 2012), sulfur compounds (Zang et al., 2018) and ferrous iron (Di Capua et al., 2015). The suspended and attached growth profiles have often been applied. The attached growth provides conditions favoring efficient autotrophic denitrification process. At this point, membrane biofilm reactor (MBfR) would be ideal for the reduction of oxidized contaminants (Martin and Nerenberg, 2012; Ontiveros-Valencia et al., 2012; Zhou et al., 2017; M. Ziv-El et al., ). When hydrogen gas is supplied from the interior of membrane, an autotrophic biofilm layer forms on the membrane surface and suitable environmental conditions for denitrification are provided. This $\mathrm{H}_{2}$-based MBfR has advantage of high gas utilization efficiency, low energy consumption and small reactor volumes (Martin et al., 2012).
Studies related to simultaneous removal of nitrate and pesticides are scanty. To our knowledge, no study on the removal of endosulfan from ground water is available by MBfR. Most studies in this connection have been carried out involving the simultaneous removal of nitrate and pesticides in wastewater treatment system with external organic carbon sources (Ritmann, 2006, Choi et al., 2006; Ginige et al., 2004). However, we have focused on the evaluation of MBfR performance in terms of its potential for simultaneous removal of nitrate and endosulfan from groundwater. MBfR was operated under varying operational conditions for maximum removals from groundwaters.

\section{Materials and Methods}

Membrane biofilm reactor (MBfR) set-up and operational conditions : Fig. 1 shows a schematic diagram of MBfR used in this study. Hollow-fiber membranes (P5S polypropylene) with inner diameter of $0.24 \mathrm{~mm}$, outer diameter of $0.31 \mathrm{~mm}$, and pore size $0.1 \mu \mathrm{m}$ was supplied from Zena Membranes Company (The Czech Republic). Membrane bundle was placed centrally within glass reactor (Fig.1). The membrane bundle consisted of 40 hollow fiber membranes with an active length of $10 \mathrm{~cm}$ and surface area of $0.0078 \mathrm{~m}^{2}$. Reactor was connected to $\mathrm{H}_{2}$ tank with pressure ranging from 2 to 6 Psi. The active working volume of MBfR was determined as $0.5 \mathrm{I}$. MBfR was operated at constant $\mathrm{pH}$ of 7.2 and temperature $30^{\circ} \mathrm{C}$, respectively. Additionally, MBfR was operated at continuous mode and influent flow rate was adjusted by a Masterflex peristaltic pump (Cole-Parmer Instrument Co., Chicago, IL) to perform varying HRTs, according to the experimental plan (Table1). A magnetic stirrer was used to mix the liquid in the reactor at $500 \mathrm{rpm}$. Influent dissolved oxygen was kept below $0.1 \mathrm{mg} \mathrm{l}^{-1}$ by continuously purging nitrogen gas. $\mathrm{pH}, \mathrm{ORP}$ and $\mathrm{DO}$ changes during the reaction were monitored continuously using a pH electrode (Mettler Toledo, Switzerland), ORP meter (Mettler Toledo, Greifensee, Switzerland) and DO electrode (Hamilton, Switzerland), respectively.

The performance of MBfR was evaluated for 237 days (Table1). Denitrification process in MBfR was optimized in Period $\mathrm{I}$ (days $0-25$ ) and II (days 26-73) at varying $\mathrm{H}_{2}$ pressures (2-6) and HRT (0.5-6). $\mathrm{NO}_{3}-\mathrm{N}$ concentration and HRT in period I was kept constant at $2.25 \mathrm{mg} \mathrm{l}^{-1}$ and $12 \mathrm{hr}$, respectively. In period $\mathrm{II}_{1} \mathrm{H}_{2}-$ pressure was adjusted to $6 \mathrm{psi}$ and the effect of HRT was tested. In period III (days74-133), MBfR was operated at $6 \mathrm{psi}_{2}$ pressure and $1 \mathrm{hr} \mathrm{HRT}$; the effect of $\mathrm{NO}_{3}-\mathrm{N}$ concentration in the range of $2.25-10 \mathrm{mg} \mathrm{I}^{-1}$ was tested. Afterwards, the effect of endosulfan concentration (0.1-15ng $\left.I^{-1}\right)$ on denitrification process was carried out. During the study, the temperature and $\mathrm{pH}$ were kept constant at 7.2 and $30^{\circ} \mathrm{C}$, respectively. $\mathrm{H}_{2}$ pressure was continuously monitored during the whole study period. Sampling was performed in MBfR effluent for measuring dissolved oxygen, $\mathrm{pH}$, $\mathrm{NO}_{3}, \mathrm{NO}_{2}$, endosulfan to determine the system performance in the bulk liquid. All data were processed in duplicate and mean values were taken. 


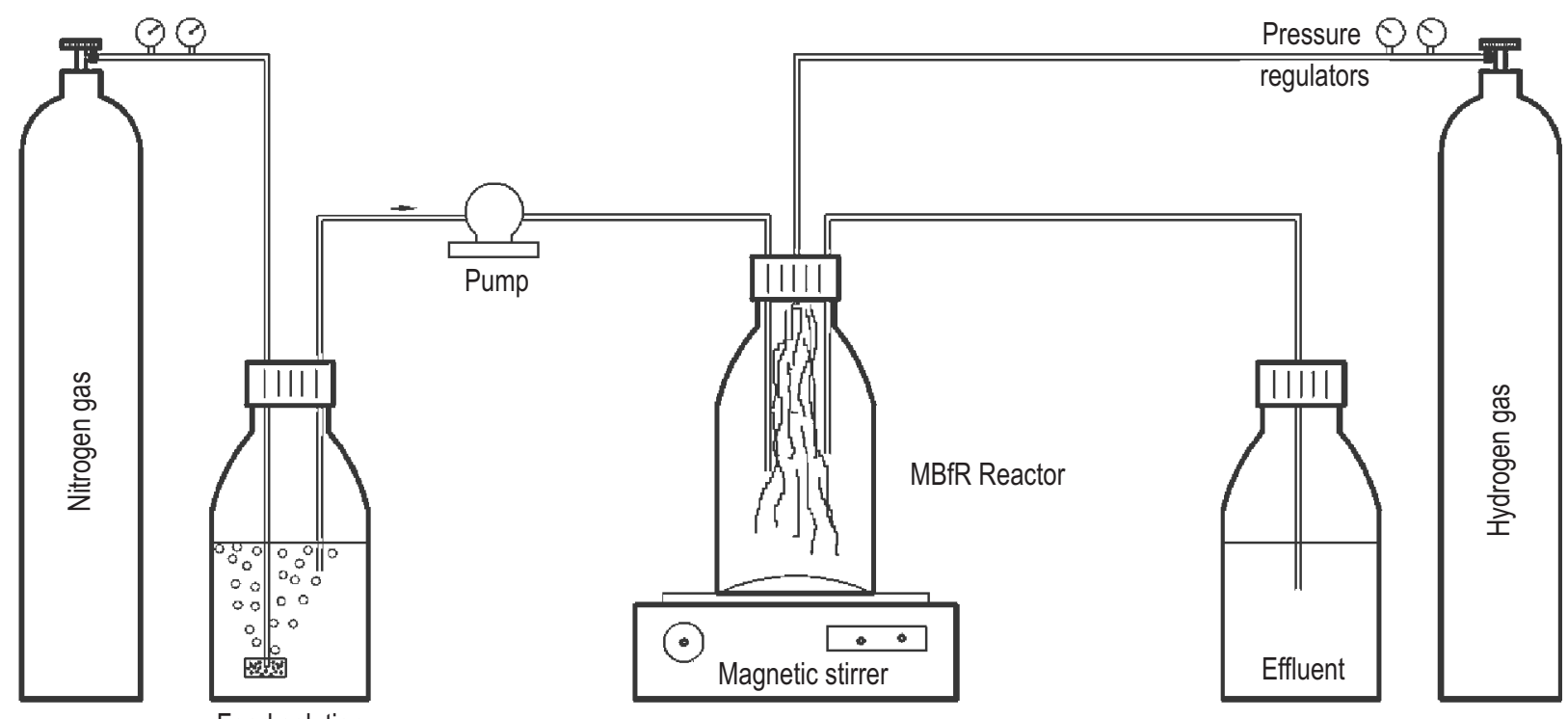

Fig. 1 : Schematic diagram of MBfR designed.

Table 1: Experimental plan

\begin{tabular}{|c|c|c|c|c|}
\hline \multirow[t]{2}{*}{ Parameters } & \multicolumn{4}{|c|}{ Periods } \\
\hline & I & II & III & IV \\
\hline Days & $0-25$ & $26-73$ & $74-133$ & $134-237$ \\
\hline HRT(hr) & 12 & $6-0.5$ & 1 & 1 \\
\hline $\mathrm{NO}_{3}-\mathrm{N}$ concentration $\left(\mathrm{mgl}^{-1}\right)$ & 2.25 & 2.25 & $2.25-10$ & 10 \\
\hline Nitrate flux $\left(\mathrm{mgNO}_{3}-\mathrm{N} \mathrm{cm}^{-2} \cdot \mathrm{d}\right)$ & 0.029 & $0.116-0.69$ & $0.346-1.54$ & 1.54 \\
\hline $\mathrm{H}_{2}$ pressure $(\mathrm{psi})$ & $2-5$ & 5 & $5-6$ & 6 \\
\hline Endosulfan concentration $\left(\mathrm{ng} \mathrm{I}^{-1}\right)$ & - & - & - & $0.1-15$ \\
\hline
\end{tabular}

Simulated groundwater and culture : MBfR was fed with synthetic ground water prepared daily. Synthetic feeding water consisted of macro and micro nutrients necessary for microorganism's growth. Trace element stock solution consisted of $\mathrm{ZnSO}_{4} \cdot 7 \mathrm{H}_{2} \mathrm{O} 100 \mathrm{mgl}^{-1}, \mathrm{MnCl}_{2} \cdot 4 \mathrm{H}_{2} \mathrm{O} 30 \mathrm{mgl}^{-1}, \mathrm{H}_{3} \mathrm{BO}_{3} 300 \mathrm{mgl}^{-1}$, $\mathrm{CuCl}_{2} \cdot 2 \mathrm{H}_{2} \mathrm{O} 10 \mathrm{mgl}^{-1}, \mathrm{Na}_{2} \mathrm{SeO}_{3} 30 \mathrm{mgl}^{-1}, \mathrm{NiCl}_{2} \cdot 6 \mathrm{H}_{2} \mathrm{O} 10 \mathrm{mgl}^{-1}$ and $\mathrm{CoCl}_{2} \cdot 6 \mathrm{H}_{2} \mathrm{O} 200 \mathrm{mg} \mathrm{l}^{-1}$ chemicals. Synthetic ground water was prepared by adding $1 \mathrm{ml}$ of trace element stock solution to synthetic feeding water containing $252 \mathrm{mg} \mathrm{l}^{-1} \mathrm{NaHCO}_{3}, 33 \mathrm{mg} \mathrm{l}^{-1}$ $\mathrm{KH}_{2} \mathrm{PO}_{4}, 50 \mathrm{mgl}^{-1} \mathrm{MgSO}_{4} \cdot 7 \mathrm{H}_{2} \mathrm{O}$ and $10 \mathrm{mgl}^{-1} \mathrm{NO}_{3}$.

Bacteria culture responsible for denitrification was originally enriched with activated sludge sample taken from domestic treatment plant located at Kayseri, Turkey. Additionally, MBfR was inoculated with sludge sample taken from denitrification tank in Seyhan Wastewater Treatment Plant Adana, Turkey. $\mathrm{H}_{2}$ gas as electron donor and nitrate as electron acceptor source were used for bacterial population. Endosulfan was procured from Sigma Aldrich Chemical Company (USA) and was $98 \%$ pure.
Analyses : Ion chromatography (Dionex ICS-3000) was used to measure the concentrations of nitrate (Dionex, Sunnyvale, CA, USA) with lon Pac AG19 guard and AS19 analytical columns. Eluent containing $8 \mathrm{mM}$ sodium carbonate $\left(\mathrm{Na}_{2} \mathrm{CO}_{3}\right)$ and $1.5 \mathrm{mM}$ sodium hydroxide $(\mathrm{NaOH})$ was prepared and used for nitrate and nitrite ion analyses at a flow rate of $1 \mathrm{ml} \mathrm{min}^{-1}$.

Endosulfan was measured following liquid-liquid extraction. Solvent used for extraction was cyclohexane. Extracted endosulfan was estimated with Shimadzu 2010 (GCMS, Shimadzu, Kyoto, Japan) gas chromatograph equipped with a split-splitless auto-injector model AOC-20i. A silica capillary column (TRB5MS), $(30 \mathrm{mx} 0.32 \mathrm{mmi} . \mathrm{d})$ with a $0.25 \mu \mathrm{m}$ thickness was used for GC separation. Helium was used as carrier gas at a constant flow of $1.21 \mathrm{ml} \mathrm{min}^{-1}$. The temperature of injection port was $240^{\circ} \mathrm{C}$ and $1 \mu \mathrm{l}$ volume was injected in splitless mode. Initial temperature was $60^{\circ} \mathrm{C}$ and increased to $180^{\circ} \mathrm{C}$ at the rate of $40^{\circ} \mathrm{C}$ $\mathrm{min}^{-1}$, this temperature was maintained for $2 \mathrm{~min}$. Afterwards, temperature was increased to $280^{\circ} \mathrm{C}$ at the rate of $5^{\circ} \mathrm{C} \mathrm{min}$. During electron impact, ionization mode an ionizing energy of 63 
$\mathrm{eV}$, and ion source temperature of $200^{\circ} \mathrm{C}$ was used. The accuracy of determination was routinely checked by using standard samples containing known amount of endosulfan. The limit of detection for endosulfan ranged from $0.001-0.1 \mathrm{ng} \mathrm{ml}^{-1}$ and the precisions ranged from $2.5-5.9 \%$.

\section{Results and Discussion}

Effect of HRT on nitrate removal performance : The effect of HRT on nitrate removal was investigated in $\mathrm{H}_{2}$ based MBfR (periods I, and II).The reactor was operated at $12 \mathrm{hr}$ HRT with various $\mathrm{H}_{2}$ pressure (2-5 psi) between 0 and 25 days (Period I), (Fig. 2). In this period, nitrate removal efficiency was relatively low (23\%) and increasing $\mathrm{H}_{2}$ pressure to 3 psi had no effect on MBfR performance corresponding to $0.029 \mathrm{mg} \mathrm{NO}_{3}{ }^{-} \mathrm{N} \mathrm{cm}^{-2} . \mathrm{d}$ nitrate removal fluxes. After day $21, \mathrm{H}_{2}$ pressure was increased to $5 \mathrm{psi}$ (Fig. 2). According to these results, increase in $\mathrm{H}_{2}$ pressure enhanced the respiratory activity of microorganism, which was correlated with the increased nitrate removal fluxes. The obtained results showed that the number of electrons was greater than the number of unoccupied electron levels of nitrate, thereby the

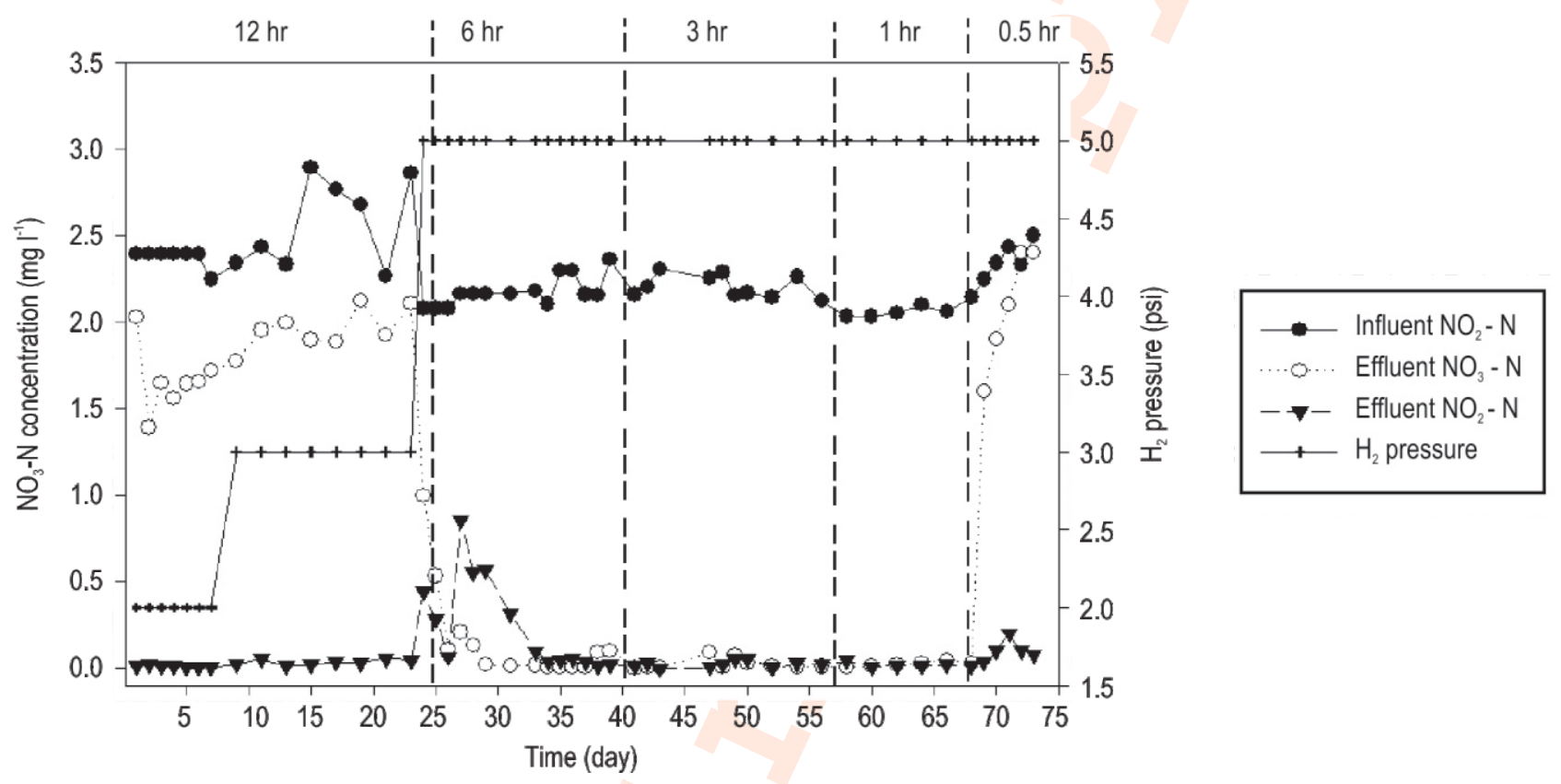

Fig. 2 : Effect of HRT on nitrate removal performance.

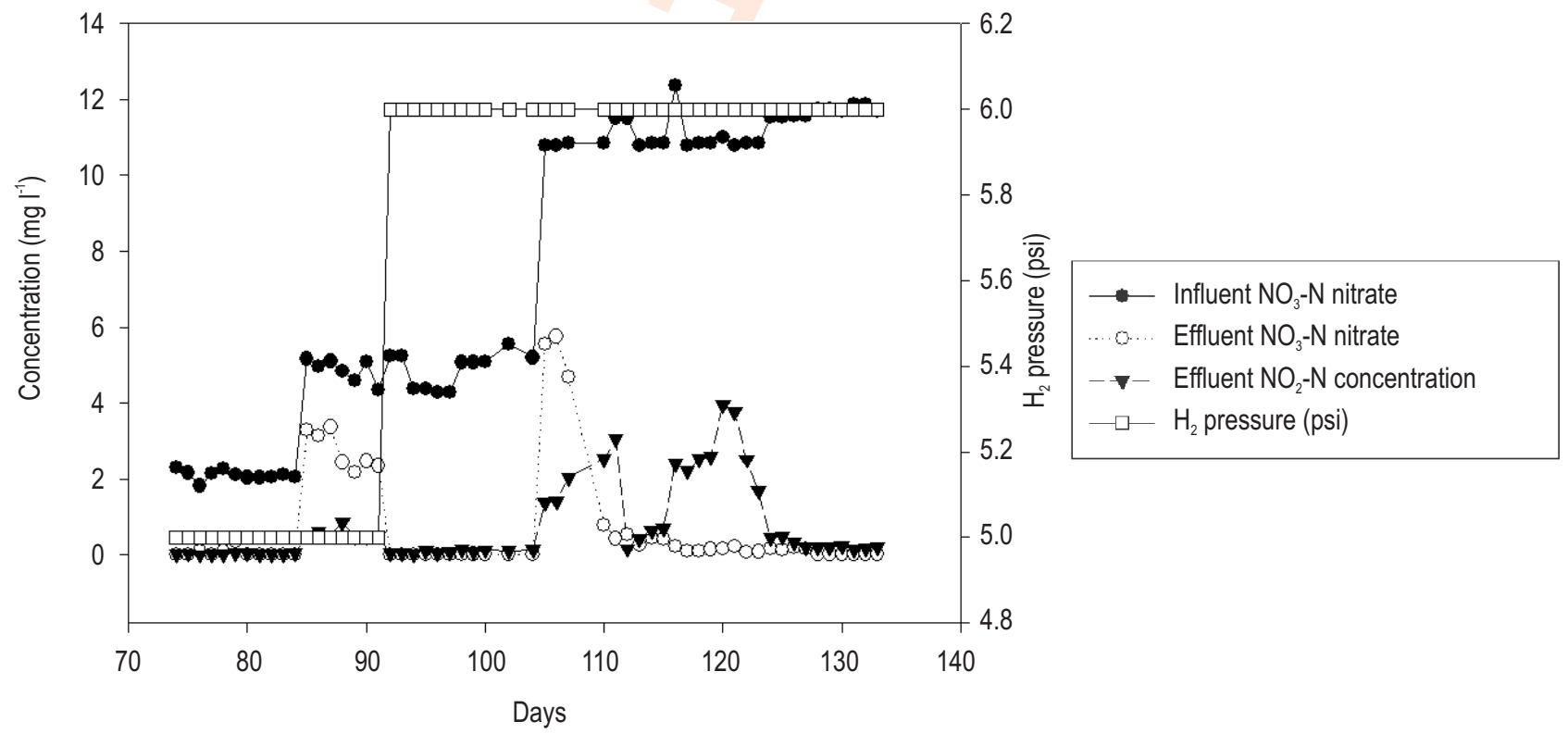

Fig. 3 : Effect of nitrate concentration on $\mathrm{H}_{2}$-based MBfR performance. 
higher unoccupied electron level was filled up resulting in higher nitrate reduction. After day 25 , HRT decreased step wise from 6$0.5 \mathrm{hr}$ corresponding to $0.116-0.69 \mathrm{mg} \mathrm{NO}_{3}^{-} \mathrm{N} \mathrm{cm}^{-2} . \mathrm{d}$ nitrate removal fluxes (period II). Nitrate removal efficiency reached to about $99 \%$ and $\mathrm{H}_{2}$ based MBfR was adapted well to the nitrate degrading conditions. Van Ginker et al. (2011) have obtained the results similar to ours. They concluded that increase in denitrification resulted from decrease in hydraulic retention time. They also observed an increase in nitrate removal by raising in fluent flow rate from $0.016 \mathrm{ml} \mathrm{min}^{-1}$ to $0.037 \mathrm{ml} \mathrm{min}^{-1}$, and reducing hydraulic retention time. However, in the last period, when HRT decreased from $1 \mathrm{hr}$ to $0.5 \mathrm{hr}$, the nitrate removal performance of the reactor decreased suddenly corresponding to $1.54 \mathrm{mg} \mathrm{NO}_{3}^{-} \mathrm{N}$ $\mathrm{cm}^{-2} . \mathrm{d}$ nitrate removal flux (Fig.2). The nitrate reduction efficiency dropped to $5.51 \%$, which should be due to insufficient reaction time for $\mathrm{H}_{2}$ oxidation and nitrate reduction. No nitrite accumulation was observed during operational conditions.

Effect of nitrate concentration : The effect of nitrate concentration was investigated in $\mathrm{H}_{2}$ based MBfR in Period III (days 74-133). Reactor was operated at $1 \mathrm{hr}$ HRT at various nitrate concentrations (2-10 $\mathrm{mg} \mathrm{NO}_{3}^{-} \mathrm{N}$ ) (Fig. 3). Days 74-85 nitrate removal efficiency was relatively low (23\%) and increasing nitrate concentration to $5 \mathrm{mg} \mathrm{l}^{-1}$ at 5 psi pressure had no effect on nitrate removal performance, corresponding to $0.77 \mathrm{mg} \mathrm{NO}_{3}-\mathrm{N}$ $\mathrm{cm}^{-2}$.d nitrate removal flux. Hasar (2009) studied nitrate flux in the MBfR in the range of 4-8 $\mathrm{g} \mathrm{N} \mathrm{m}^{-2} . d$ and achieved almost complete denitrification. Nitrate removal improved later, when $\mathrm{H}_{2}$ pressure increased to $6 \mathrm{psi}$, corresponding to $99 \%$ nitrate removal efficiency (Xia et al., 2010). Similarly, Lee and Rittmann (2002) and Schnobrich et al. (2007) had achieved complete denitrification by increasing hydrogen pressure. Nerenberg et al. (2002) achieved maximum nitrate removal of $99 \%$ at $2.5 \mathrm{psi}_{2}$ pressure and reported that higher hydrogen pressures did not increase nitrate removal. However, when nitrate concentration increased to $10 \mathrm{mg} \mathrm{l}^{-1}$, flocculations were observed initially and nitrite was observed in effluent. After day 125, the reactor was almost stable and over $99 \%$ nitrate removal was observed without nitrite accumulation.

Effect of endosulfan concentration on denitrification : The effect of endosulfan concentration on nitrate removal was investigated during the days 134-237 (period IV, Table. 1). Fig. 4 shows nitrate removal profile at various endosulfan

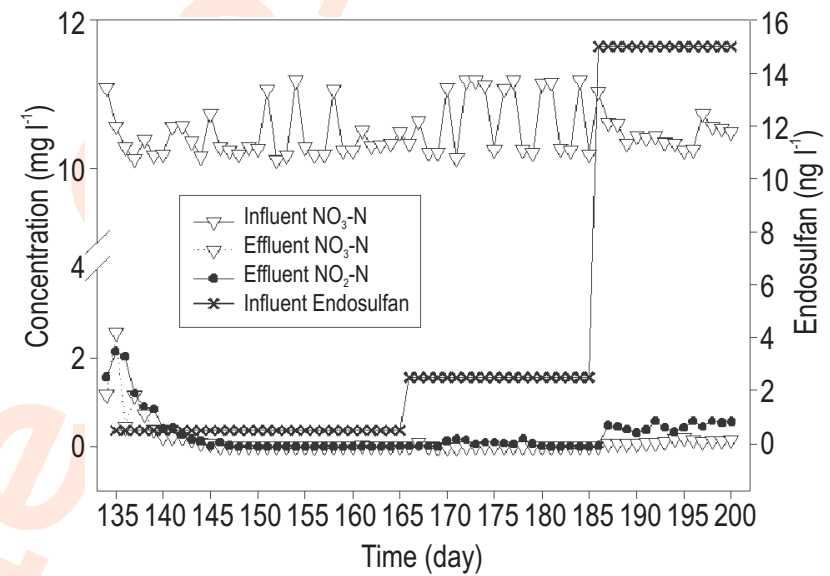

Fig. 4 : Effect of endosulfan on nitrate removal.

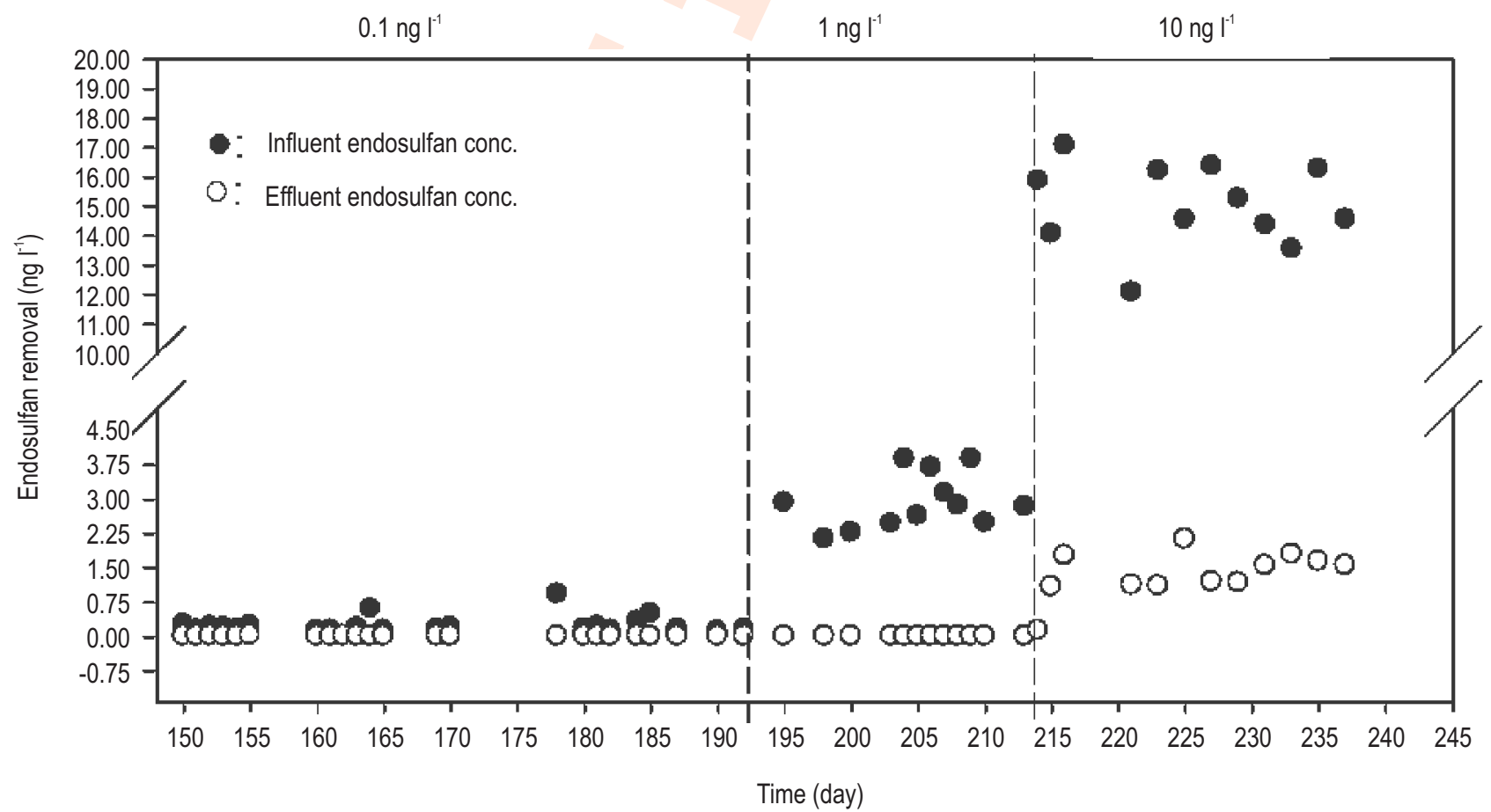

Fig. 5 : Endosulfan removal. 
concentrations, while Fig. 5 shows endosulfan removal profile. The results revealed that nitrate removal was not adversely affected by endosulfan, and endosulfan removal was over $99 \%$ in $\mathrm{H}_{2}$-based MBfR. Only small increase in effluent endosulfan and nitrate was observed when endosulfan concentration was $10 \mathrm{ng}$ $\mathrm{I}^{-1}$. Additionally, endosulfan had a tendency to accumulate in the reactor when influent concentration was set to above1 $\mathrm{ng} \mathrm{l}^{-1}$ (Fig. 5 ), which was confirmed by increase in influent endosulfan values. Aslan and Turkman (2004) had achieved complete nitrate removal below $1000 \mu \mathrm{g} \mathrm{I}^{-1}$ endosulfan $(\alpha+\beta)$ concentration and they stated that above this concentration value microbial activity was inhibited.

In this study, nitrate reduction by $\mathrm{H}_{2}$ based MBfR was investigated under endosulfan availability. Our results showed that nitrate removal decreased remarkably as HRT was decreased and increased directly proportional to increase in $\mathrm{H}_{2}$ pressure. Simultaneous endosulfan $\left(15 \mathrm{ng} \mathrm{l}^{-1}\right)$ and nitrate $\left(10 \mathrm{mg} \mathrm{I}^{-}\right.$ ${ }^{1} \mathrm{NO}_{3}-\mathrm{N}$ ) removal was achieved with high efficiencies (over $99 \%$ ). The results of this study clearly demonstrated that $\mathrm{H}_{2}$ based MBfR was effective for removing simultaneous endosulfan and nitrate from the contaminated ground waters. Therefore, the MBfR proposed could help in reducing the pesticide contamination in ground water and will be useful to meet drinking water standards where ground water is used as drinking water source. Additionally, high removal rates obtained from this reactor operation showed that additional treatment unit is not needed. However, pretreatment should be taken into account to remove suspended solids before MBfR operation along with disinfection after treatment.

\section{References}

ATSDR: Toxicological profile information sheet (2015).

Aslan, Ş. and A. Türkman: Simultaneous biological removal of endosulfan $(\alpha+\beta)$ and nitrates from drinking waters using wheat straw as substrate. Environ. Int., 30, 449-455 (2004).

Choi, K.J., S.G. Kim, C.W. Kim and J.K. Park: Removal efficiencies of endocrine disrupting chemicals by coagulation/flocculation, ozonation, powdered/granular activated carbon adsorption, and chlorination. Korean J. Chem. Eng., 23, 399-408 (2006).

Di Capua, F., S. Papirio, P.N. Lens and G. Esposito: Chemolithotrophic denitrification in biofilm reactors. Chem. Eng. J., 280, 643-657 (2015).

Ergas, S.J. and A.F. Reuss: Hydrogenotrophic denitrification of drinking water using a hollow fibre membrane bioreactor. J. Water Supply Res. Technol. AQUA, 50, 161-171 (2001).

Feng, L., G. Yang, L. Zhu, X. Xu, F. Gao, J. Mu and Y. Xu: Enhancement removal of endocrine-disrupting pesticides and nitrogen removal in a biofilm reactor coupling of biodegradable Phragmites communis and elastic filler for polluted source water treatment. Bioresour. Technol., 187, 331-337 (2015).

Ginige, M.P., P. Hugenholtz, H. Daims, M. Wagner, J. Keller and L.L. Blackall: Use of stable-isotope probing, full-cycle rRNA analysis, and fluorescence in situ hybridization-microautoradiography to study a methanol-fed denitrifying microbial community. Appl.
Environ. Microbiol., 70, 588-596 (2004).

Hakeem K.R., A. Ahmad, M. Iqbal, S. Gucel and M. Ozturk: Nitrogen efficient rice genotype can reduce nitrate pollution. Environ. Sci. Pollut. Res.,18,1184-1193 (2011).

Hakeem, K.R., M. Ozturk, M. Sabir and M.S. Akhtar: Nitrate and nitrogen oxides: Sources, health effects and their remediation. Rev. Environ. Contam. Toxicol., 242,183-217 (2017).

Hasar, H.: Simultaneous removal of organic matter and nitrogen compounds by combining a membrane bioreactor and a membrane biofilm reactor. Bioresour. Technol., 100, 2699-2705 (2009).

Lee, K.C. and B.E. Rittmann: Applying a novel auto hydrogen otrophic hollow-fiber membrane biofilm reactor for denitrification of drinking water. WaterRes., 36, 2040-2052 (2002).

Martin, K.J. and R. Nerenberg: The membrane biofilm reactor (MBfR) for water and wastewater treatment: Principles, applications, and recent developments. Bioresour. Technol., 122, 83-94 (2012).

Mirvish, S.S.: N-nitroso compounds, nitrite and nitrate: Possible implications for the causation of human cancer. In: Proceedings of the Conference on Nitrogen as a Water Pollutant (Ed.: S.H. Jenkins) Pergamon, Birmingham, England, pp. 195-207 (2013).

Nerenberg, R. and B.E. Rittmann: Hydrogen-based, hollow-fiber membrane biofilm reactor for reduction of perchlorate and other oxidized contaminants. Water Sci. Technol., 49, 223-230 (2004).

Nerenberg, R., B.E. Rittmann and I. Najm: Perchlorate reduction in ahydrogen-based membrane-biofilm reactor. J. Am. Water Works Assn., 94, 103-114 (2002).

Ontiveros-Valencia, A., M. Ziv-El, H.P. Zhao, L. Feng, B.E. Rittmann and R. Krajmalnik-Brown: Interactions between nitrate-reducing and sulfate-reducing bacteria coexisting in a hydrogen-fed biofilm. Environ. Sci. Technol., 46, 11289-11298 (2012).

Ozturk, M., S. Gucel, S. Sakcali and S. Baslar: Nitrate and edible plants in the Mediterranean Region of Turkey: An Overview. In: Nitrate in Leafy Vegetables-Toxicity and Safety Measures (Eds.: S. Umar, N.A. Anjum and N.A. Khan) Bio-Green Books. New DelhiBangalore, India, pp. 17-51 (2013).

Puig, S., M. Coma, J. Desloover, N. Boon, J. Colprim and M.D. Balaguer: Autotrophic denitrification in microbial fuel cells treating low ionic strength waters. Environ. Sci. Technol., 46, 2309-2315(2012).

Rittmann, B.E.: The membrane biofilm reactor: The natural partnership of membranes and biofilm. Water Sci. Technol., 53, 219-225 (2006).

Rittmann, B.E.: Environmental biotechnology in water and wastewater treatment. J. Environ. Eng., 136, 348-353 (2009).

Schnobrich, M.R., B.P. Chaplin, M.J. Semmens and P.J. Novak: Stimulating hydrogenotrophic denitrification in simulated groundwater containing high dissolved oxygen and nitrate concentrations. WaterRes., 41, 1869-1876 (2007).

Shin, J.H., B.C. Kim, O. Choi, H. Kim and B.I. Sang: Analysis of microbial communities in biofilms from CSTR-Type hollow fiber membrane biofilm reactors for autotrophic nitrification and hydrogenotrophic denitrification. J. Microbiol. Biotechnol., 25, 1670-1679 (2015).

Van Ginkel, S.W., Z. Yang, B.O. Kim, M. Sholin and B.E. Rittmann: Effect of $\mathrm{pH}$ on nitrate and selenate reduction in flue gas desulfurization brine using the $\mathrm{H}_{2}$-based membrane biofilm reactor (MBfR). Water Sci. Technol., 63, 2923-2928 (2011).

Westerman, P.W. and J.R. Bicudo: Management considerations for organic waste use in agriculture. Bioresour. Technol., 96, 215-221 (2005). 
Xia, S., F. Zhong, Y. Zhang, H. Li and X. Yang: Bio-reduction of nitrate from groundwater using a hydrogen-based membrane biofilm reactor. J. Environ. Sci., 22, 257-262 (2010).

Zhang, R.C., X.J. Xu, C. Chen, D.F. Xing, B. Shao, W.Z. Liu, A.J. Wang, D.J. Lee and N.Q. Ren: Interactions of functional bacteria and their contributions to the performance in integrated autotrophic and heterotrophic denitrification. Water Res., 143, 355-366 (2018).

Zhou, C., Z. Wang, A. Ontiveros-Valencia, M. Long, C.Y. Lai, H.P. Zhao,
S. Xia and B.E. Rittmann: Coupling of Pd nanoparticles and denitrifying biofilm promotes $\mathrm{H}_{2}$-based nitrate removal with greater selectivity towards $\mathrm{N}_{2}$. Appl. Catal., B, 206, 461-470 (2017).

Ziv-El, M., S.C. Popat, K. Cai, R.U. Halden, R. Krajmalnik-Brown and B.E. Rittmann: Managing methanogens and homoacetogens to promote reductive dechlorination of trichloroethene with direct delivery of $\mathrm{H}_{2}$ in a membrane biofilm reactor. Biotechnol. Bioeng., $109,2200-2210$ (2012). 